\title{
Water-separated part of Chloranthus serratus alleviates lipopolysaccharide- induced RAW264.7 cell injury mainly by regulating the MAPK and Nrf2/HO-1 inflammatory pathways
}

Shuping Sun ${ }^{1,2,3^{*}}$ (D), Yunyan Du ${ }^{2,3}$, Chuanliu Yin ${ }^{2,3}$, Xiaoguo Suo ${ }^{2,3}$, Rui Wang ${ }^{2,3}$, Rongping Xia ${ }^{2,3}$ and Xiaoping Zhang ${ }^{1 *}$

\begin{abstract}
Background: Chloranthus serratus (Chloranthaceae) has been used to treat bruises, rheumatoid and bone pain. However, the anti-inflammatory mechanisms of $C$. serratus in vitro have not been fully elucidated. The present study aimed to explore the anti-inflammatory activity and potential mechanisms of $C$. serratus's separated part of water (CSSPW) in lipopolysaccharide (LPS)-induced RAW264.7 cells.

Methods: The concentrations of CSSPW were optimized by CCK-8 method. Nitric oxide (NO) content was detected by one-step method. The levels of inflammatory cytokines were determined by enzyme-linked immunosorbent assay (ELISA). Gene expression of inducible nitric oxide synthase (iNOS) and cyclooxygenase-2 (COX-2) was detected by real-time quantitative PCR (qPCR). Immunofluorescence and DCFH-DA fluorescent probes were used to detect p65 nuclear translocation and reactive oxygen species (ROS) content, respectively. Western blotting was used to assay the protein expression of mitogen-activated protein kinases (MAPK), nuclear factor-kappa B (NF-kB) and nuclear transcription factor E2 related factor 2/haem oxygenase-1 (Nrf2/HO-1) pathways.

Results: The final concentrations of $15 \mathrm{ng} / \mathrm{mL}, 1.5 \mu \mathrm{g} / \mathrm{mL}$ and $150 \mu \mathrm{g} / \mathrm{mL}$ were selected as low, medium and high doses of CSSPW, respectively. CSSPW treatment significantly reduced the generation of $\mathrm{NO}$, tumour necrosis factora (TNF-a), interleukin-6 (IL-6), prostaglandinE $E_{2}\left(\mathrm{PGE}_{2}\right)$, iNOS mRNA and COX-2 mRNA in response to LPS stimulation. Furthermore, the protein expression of the MAPK and NF-KB pathways was suppressed by CSSPW treatment, as well as p65 nuclear translocation and ROS production. In contrast, the protein expression of the Nrf2/HO-1 pathway was markedly upregulated.
\end{abstract}

Conclusions: CSSPW exerts its anti-inflammatory effect via downregulating the production of pro-inflammatory mediators, inhibiting the activation of NF-KB and MAPK pathways, as well as activating Nrf2/HO-1 pathway in LPSinduced RAW264.7 cells.

Keywords: Chloranthus serratus, LPS, RAW264.7 cells, Anti-inflammatory, MAPK pathway, NF-kB pathway

\footnotetext{
* Correspondence: sun5587001@163.com; 89282111@qq.com

${ }^{1}$ College of Life Science, Anhui Normal University, Wuhu 241000, Anhui,

China

Full list of author information is available at the end of the article
}

(c) The Author(s). 2019 Open Access This article is distributed under the terms of the Creative Commons Attribution 4.0 International License (http://creativecommons.org/licenses/by/4.0/), which permits unrestricted use, distribution, and reproduction in any medium, provided you give appropriate credit to the original author(s) and the source, provide a link to the Creative Commons license, and indicate if changes were made. The Creative Commons Public Domain Dedication waiver (http://creativecommons.org/publicdomain/zero/1.0/) applies to the data made available in this article, unless otherwise stated. 


\section{Background}

Inflammation is a defence response against a variety of harmful stimuli (e.g., tissue injury, infection and stimulants), which is also the most common pathological process in human diseases $[1,2]$. Inflammation is generally divided into acute and chronic inflammation, which can lead to a series of inflammatory diseases such as rheumatoid arthritis and gastritis. If not treated in time, inflammation may further develop into various cancers $[3,4]$.

The occurrence of inflammation is accompanied by the production of inflammatory mediators such as prostaglandin $\mathrm{E}_{2}\left(\mathrm{PGE}_{2}\right)$, interleukin-6 (IL-6), tumour necrosis factor- $\alpha$ (TNF- $\alpha)$ and nitric oxide (NO). The overexpression of these inflammatory mediators may cause serious damage to cells and tissues, even resulting in organ failure $[3,5]$. Moreover, two pro-inflammatory enzymes, inducible nitric oxide synthase (iNOS) and cyclooxygenase-2 (COX-2), play synergistic roles in inflammatory diseases, and drugs with dual inhibitory effects on iNOS and COX-2 mRNA have great antiinflammatory potential [6]. Hence, inhibiting the overexpression of related inflammatory mediators is an effective method to control inflammation.

At present, there are many anti-inflammatory chemicalbased drugs, such as indomethacin, prednisone, ibuprofen and aspirin. However, these drugs can damage the kidneys [7]. Fortunately, traditional Chinese medicine (TCM) provides an alternative or better options for patients with inflammation. TCM has good anti-inflammatory and immunological activity, which is used to treat inflammation with multi-component, multi-link and multi-target characteristics [8]. Therefore, it is of great significance to develop natural anti-inflammatory drugs.

Chloranthus serratus (Thunb.) Roem. et Schalt (Chloranthaceae family), mainly produced in Anhui, Zhejiang, Guangxi, Yunnan and other provinces of China, can promote blood circulation, prevent inflammation and other diseases [9]. According to the records in the Modern Chinese Pharmacy Dictionary, C. serratus can relax muscles and joints, reduce swelling, relieve pain, treat bruises, fractures, rheumatism, etc. [10]. Its root is often used as medicine and has obvious anti-inflammatory activity in vivo [11]. Our previous study has shown that $C$. serratus's separated part of water (CSSPW) has antiinflammatory activity in rats. However, the antiinflammatory mechanisms of CSSPW in lipopolysaccharide (LPS)-induced RAW264.7 cells remain unclear.

This study aimed to investigate the anti-inflammatory effects and potential mechanisms of CSSPW on LPSstimulated RAW264.7 cells. We determined the production of corresponding inflammatory factors and mRNA levels of pro-inflammatory mediators. Finally, the levels of related signal pathways were detected to clarify the anti-inflammatory mechanisms.

\section{Methods \\ Reagents}

The RAW264.7 cells (TCM13) were purchased from the American Type Culture Collection (Rockville, MD, USA). LPS was obtained from Beijing Solarbio Co., Ltd. (Beijing, China). CCK-8 kit was purchased from Jiangsu Kaiji Biotechnology Co., Ltd. (Jiangsu, China). NO was obtained from Jiancheng Biotechnology Co., Ltd. (Nanjing, China). TNF- $\alpha$, IL-6 and PGE $_{2}$ enzyme linked immunosorbent assay (ELISA) kits were provided by Shanghai Youchu Trading Co., Ltd. (Shanghai, China). Nuclear transcription factor E2 related factor 2 (Nrf2), p65 and $\beta$-tubulin antibodies were obtained from Proteintech Group, Inc. (USA). P-p65 and p-p38antibodies were obtained from Affinity Biosciences (USA). ERK1/2, p-ERK1/2, p38, p-JNK, JNK antibodies and DCFH-DA kit were purchased from Beyotime Biotechnology Co., Ltd. (Shanghai, China). $\beta$-actin, heme oxygenase-1 (HO1) and IgG antibodies were purchased from Boster Biological Engineering Co., Ltd. (Wuhan, China). GAPDH, iNOS and COX-2 primers were obtained from Servicebio Biotechnology Co., Ltd. (Wuhan, China), etc.

\section{Sample preparation}

C. serratus was harvested in Yulin (Guangxi, China). Referring to the Modern Chinese Pharmacy Dictionary [10], it was determined to be genuine by Professor Zhu JH of Wannan Medical College, and a voucher specimen of the plant (ANUB14096) was deposited in the Herbarium Centre, Anhui Normal University, China. After washing and drying naturally, the root was separated and crushed to coarse powder, which was stored at room temperature.

The coarse powder of the C. serratus root was immersed into 12 times $75 \%$ ethanol for $0.5 \mathrm{~h}$ and refluxed for $1.5 \mathrm{~h}$, then extracted with 10 times and 8 times $75 \%$ ethanol for $1 \mathrm{~h}$, respectively. The tertiary filtrate was combined and the solvent was recovered at low pressure until alcohol free, then extracted successively with an equal amount of chloroform, ethyl acetate and n-butanol for three times. The residual phase after extraction by n-butanol was the aqueous phase. Subsequently, the aqueous phase was concentrated, dried and crushed to obtain the waterseparated part, which was stored at room temperature in a desiccator. Extraction rate $(\%)=$ mass of the waterseparated part (g) / mass of coarse powder from the root (g) $\times 100 \%$, which was $1.94 \%$.

\section{Cell culture and viability assay}

RAW264.7 cells were cultured in high glucose Dulbecco's modified Eagle's medium (DMEM) containing 10\% $(\mathrm{v} / \mathrm{v})$ foetal bovine serum (FBS, HyClone, USA) and $1 \%$ penicillin-streptomycin at $37^{\circ} \mathrm{C}$ in a humidified atmosphere with $5 \% \mathrm{CO}_{2}$. The medium was replaced every 2 
days. Cells in their logarithmic growth stage were chosen for follow-up experiments.

Cell viability was detected by CCK- 8 method. The cells were seeded in 96-well culture plates $\left(2 \times 10^{4}\right.$ cells/well $)$ and treated with $100 \mu \mathrm{L}$ of different concentrations of CSSPW (0, 11.5, 23, 46, 92, 184, 368, 736 and $1472 \mu \mathrm{g} /$ $\mathrm{mL})$ and LPS $(0,0.5,1.0,1.5$ and $2.0 \mu \mathrm{g} / \mathrm{mL})$ for $24 \mathrm{~h}$. Then $10 \mu \mathrm{L}$ of CCK-8 solution was added to each well except the blank group. Next, the 6-well plates were placed in the incubator and cultured for $2 \mathrm{~h}$. OD values were measured at $450 \mathrm{~nm}$ wavelength and $600 \mathrm{~nm}$ reference wavelength with a microplate reader (Shenzhen Sante Electronics Co., Ltd., Shenzhen, China). Cell viability $(\%)=\left(\mathrm{OD}_{\text {drug group }}-\mathrm{OD}_{\text {blank group }}\right) /(\mathrm{OD}$ control group - OD blank group $) \times 100 \%$.

\section{Experimental design}

The cells were inoculated into a 6-well plate and divided into control (Con) group, model (LPS) group, dexamethasone-positive (Dex) group, and low-dose, middle-dose and high-dose CSSPW groups. After $1 \mathrm{~h}$ of adherent growth, the drug solution was individually added to the corresponding wells and cultured for $0.5 \mathrm{~h}$. Then, $1 \mathrm{~mL}$ of LPS solution was added to the wells, except those of the Con group. After inoculation for $24 \mathrm{~h}$, the cell morphology was observed and photographed with an OLYMPUS inverted microscope (Kunshan Nuopusen Laboratory Products Technology Co., Ltd., Kunshan, China).

\section{Determination of the inflammatory factors NO, TNF-a, IL- 6 and $\mathrm{PGE}_{2}$}

The cells were co-treated with CSSPW $(15 \mathrm{ng} / \mathrm{mL}$, $1.5 \mu \mathrm{g} / \mathrm{mL}$ and $150 \mu \mathrm{g} / \mathrm{mL})$ and LPS $(1 \mu \mathrm{g} / \mathrm{mL})$ for $24 \mathrm{~h}$. After centrifugation, cell-free supernatants were collected for assaying NO, TNF- $\alpha$, IL- 6 and $\mathrm{PGE}_{2}$ production. The NO content was measured by one-step method in accordance with the manufacturer's instructions. The levels of TNF- $\alpha$, IL- 6 and $\mathrm{PGE}_{2}$ were determined by ELISA using the automatic biochemical analyser (Hitachi, Japan) according to the protocols of commercial assay kits.

\section{Real-time quantitative PCR analysis}

The expression of COX-2 and iNOS mRNA was detected by real-time fluorescence quantitative PCR. The medium was removed, and the cells were reserved for RNA extraction. The purity of the RNA was determined with a NanoDrop 2000 Ultramicrospectrophotometer (Thermo Fisher Scientific, USA).

The reverse transcription was as follows: RNA solution $(2 \mu \mathrm{L})$, oligo $(\mathrm{dT}) 18(1 \mu \mathrm{L})$, and deionized water $(9 \mu \mathrm{L})$ were added and incubated at $65^{\circ} \mathrm{C}$ for $5 \mathrm{~min}$. Then, $5 \times$ reaction buffer $(4 \mu \mathrm{L}), 10 \mathrm{mM}$ dNTP mix $(2 \mu \mathrm{L})$, Ribo Lock
RNase inhibitor $(1 \mu \mathrm{L})$ and RevertAi M-MuLVreverse transcriptase $(1 \mu \mathrm{L})$ were added. The final solution was incubated at $42{ }^{\circ} \mathrm{C}$ for $60 \mathrm{~min}$ and then at $70{ }^{\circ} \mathrm{C}$ for $5 \mathrm{~min}$ to reverse transcribe RNA into $\mathrm{cDNA}$.

The iNOS primers used were 5'-CACCTTGGAAGAGG AGCAACTAC-3' (Forward) and 5'-GAGCAAAGGC GCAGAACTGA-3'(Reverse). The COX-2 primers used were 5'-ATAGACGAAATCAACAACCCCG-3' (Forward) and 5'-GGATTGGAAGTTCTATTGGCAG-3' (Reverse). GAPDH was used as a positive control and the primers used were $5^{\prime}$-CCTCGTCCCGTAGACAAAATG-3' (Forward) and $5^{\prime}$-TGAGGTCAATGAAGGGGTCGT-3' (Reverse).

PCR was performed as follows: $95^{\circ} \mathrm{C}$ for $10 \mathrm{~min} ; 95^{\circ} \mathrm{C}$ for $15 \mathrm{~s}$ and $60^{\circ} \mathrm{C}$ for $60 \mathrm{~s}$ for 40 cycles and $72^{\circ} \mathrm{C}$ for 1 min. Finally, the melting curve was obtained. $\mathrm{Ct}$ values of the output were quantitatively analysed by the $2^{-\Delta \Delta \mathrm{Ct}}$ method.

\section{Western blotting analysis}

The RAW264.7 cells were inoculated in 6-well plates, and the culture medium was discarded after treatment with CSSPW $(15 \mathrm{ng} / \mathrm{mL}, 1.5 \mu \mathrm{g} / \mathrm{mL}$ and $150 \mu \mathrm{g} / \mathrm{mL})$ and LPS $(1 \mu \mathrm{g} / \mathrm{mL})$ for $24 \mathrm{~h}$. The cells were lysed with lysate (RIPA:PMSF:phosphatase inhibitor $=100: 1: 1$ ) for $10 \mathrm{~min}$ on ice, followed by centrifugation at $12,000 \mathrm{r} / \mathrm{min}$ and $4{ }^{\circ} \mathrm{C}$ for $20 \mathrm{~min}$. The target proteins were collected and isolated by electrophoresis (Bio-Rad, USA) with 8 and $10 \%$ SDS-PAGE, then transferred to nitrocellulose (NC) membranes. After blocking with 5\% skim milk at room temperature for $2 \mathrm{~h}$, the NC membranes were incubated with the primary antibodies specific to Nrf2, HO-1, p65, p-p65, ERK, p-ERK, p38, p-p38, JNK, p-JNK, $\beta$-actin and $\beta$-tubulin at $4{ }^{\circ} \mathrm{C}$ overnight, subsequently incubated with the corresponding HRP-conjugated secondary antibodies at room temperature for $1 \mathrm{~h}$. Then the ECL developer was added to expose the bands by Amersham Imager600 Ultra-sensitive Multi-function Imager (General Electric Co., Ltd., USA). Grey values were obtained by ImageJ software to quantitatively analyse protein expression.

\section{Detection of p65 nuclear transcription}

Cover slips were placed in the wells to allow the cells to adhere to them. RAW264.7 cells were inoculated in a 6well plate, then the medium was discarded after treatment with CSSPW $(15 \mathrm{ng} / \mathrm{mL}, 1.5 \mu \mathrm{g} / \mathrm{mL}$ and $150 \mu \mathrm{g} / \mathrm{mL})$ and LPS $(1 \mu \mathrm{g} / \mathrm{mL})$ for $24 \mathrm{~h}$. The stimulated RAW264.7 cells were fixed with $4 \%$ paraformaldehyde for $30 \mathrm{~min}$, and then permeabilized with $0.2 \%$ Triton X-100 for $10 \mathrm{~min}$. After incubation with the blocking solution for $2 \mathrm{~h}$, the cells were incubated with the p65 antibody at $4{ }^{\circ} \mathrm{C}$ overnight and then incubated with FITC-labelled goat anti-rabbit IgG at $37^{\circ} \mathrm{C}$ for $1 \mathrm{~h}$. Nuclei were stained with DAPI staining agent for $5 \mathrm{~min}$ in the dark. Then, the cells were 
sealed, observed and photographed with a TCSSP8 Laser Confocal Microscope (Leica, Germany).

\section{Determination of ROS levels}

ROS levels were detected by fluorescent probes. DCFHDA was diluted (1:200) in serum-free medium to a final concentration of $50 \mu \mathrm{mol} / \mathrm{L}$. After the cells were cocultured for $24 \mathrm{~h}$ with CSSPW $(15 \mathrm{ng} / \mathrm{mL}, 1.5 \mu \mathrm{g} / \mathrm{mL}$ and $150 \mu \mathrm{g} / \mathrm{mL})$ and LPS $(1 \mu \mathrm{g} / \mathrm{mL})$ in a six-well plate, the cell culture medium was removed, and $1 \mathrm{~mL} /$ well of the diluted DCFH-DA was added and incubated at $37^{\circ} \mathrm{C}$ for $1 \mathrm{~h}$ in the incubator. The cells were washed with serum-free cell culture medium for 3 times to sufficiently remove the DCFH-DA that did not enter the cells. Then, $1 \mathrm{~mL}$ PBS was added, and using an excitation wavelength of $488 \mathrm{~nm}$ and an emission wavelength of $525 \mathrm{~nm}$, the fluorescence intensity was observed and photographed under an inverted fluorescence microscope. Then the generation rate of ROS was obtained by ImageJ software and analysed quantitatively.

\section{UV fingerprint analysis}

The solution of the sample was obtained by accurately weighing $0.05 \mathrm{~g}$ of CSSPW and dissolving it to $1 \mathrm{mg} / \mathrm{mL}$ with distilled water. Using Hitachi U-5100 spectrophotometer (Hitachi High-Tech Science Corporation, Japan), blank correction with distilled water, scanning under the following spectral conditions: data mode: Abs; scanning range: $190-500 \mathrm{~nm}$; scanning speed: $400 \mathrm{~nm} / \mathrm{min}$; delaying: $0 \mathrm{~s}$; response: fast; sampling interval: $1.0 \mathrm{~nm}$; cycle time: $1.0 \mathrm{~min}$; slit width: $5.00 \mathrm{~nm}$.

\section{Statistical analysis}

For statistical analysis, SPSS17.0 software was employed. All data were expressed as mean $\pm \mathrm{SD}$, and one-way analysis of variance was used to compare the means of multiple samples, then, LSD was performed for the post hoc test. $p<0.05$ indicated a significant difference.

\section{Results}

\section{Cell viability}

As shown in Fig. 1, the cell viability was almost $100 \%$ at CSSPW concentrations of $0-184 \mu \mathrm{g} / \mathrm{mL}$ and LPS concentrations of $0-0.5 \mu \mathrm{g} / \mathrm{mL}$. The CSSPW concentration in the range of $368-1472 \mu \mathrm{g} / \mathrm{mL}$ and LPS concentrations in the range of $1.5-2.0 \mu \mathrm{g} / \mathrm{mL}$ both had obvious effects on cell viability $(p<0.01)$. CSSPW did not obviously affect cell viability up to $184 \mu \mathrm{g} / \mathrm{mL}$ in the medium. Based on the preliminary results, the experimental concentrations of CSSPW were finally determined to be 15 $\mathrm{ng} / \mathrm{mL}, 1.5 \mu \mathrm{g} / \mathrm{mL}$ and $150 \mu \mathrm{g} / \mathrm{mL}$, and the experimental concentration of LPS was $1 \mu \mathrm{g} / \mathrm{mL}$ [12].

\section{Effects on cell morphology}

Cell morphology can reflect the health of cells, which is considered one of the noteworthy characteristics of the anti-inflammatory effect. Figure 2 shows that LPSchallenged cells formed more pseudopods of irregular shapes and more cellular vacuoles than those of the Con group, which indicated that LPS stimulation was successful. However, after treatment with CSSPW (15 ng/ $\mathrm{mL}, 1.5 \mu \mathrm{g} / \mathrm{mL}$ and $150 \mu \mathrm{g} / \mathrm{mL}$ ), the number of pseudopods, irregular shapes and vacuoles was significantly reduced. The effect was more pronounced at higher concentrations.

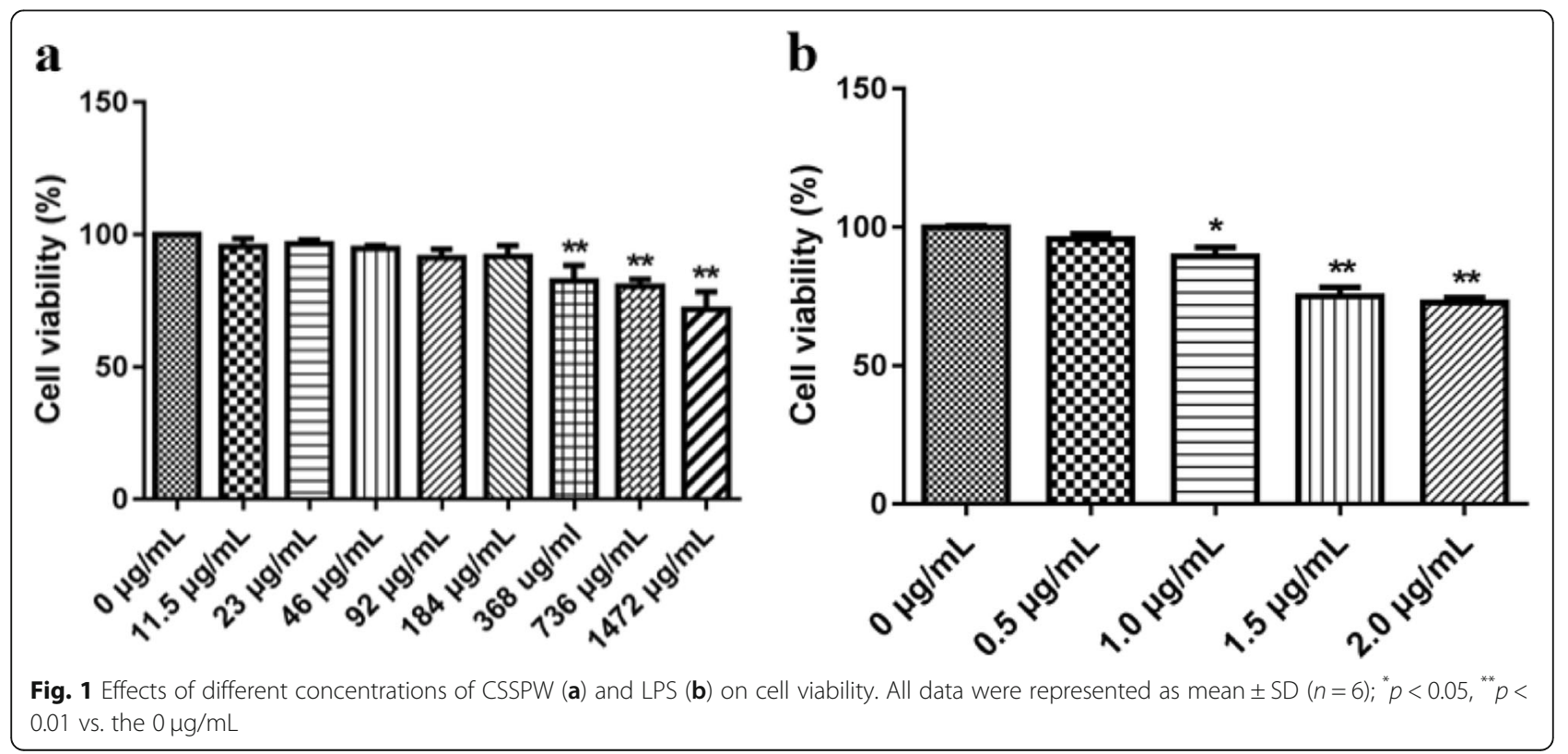




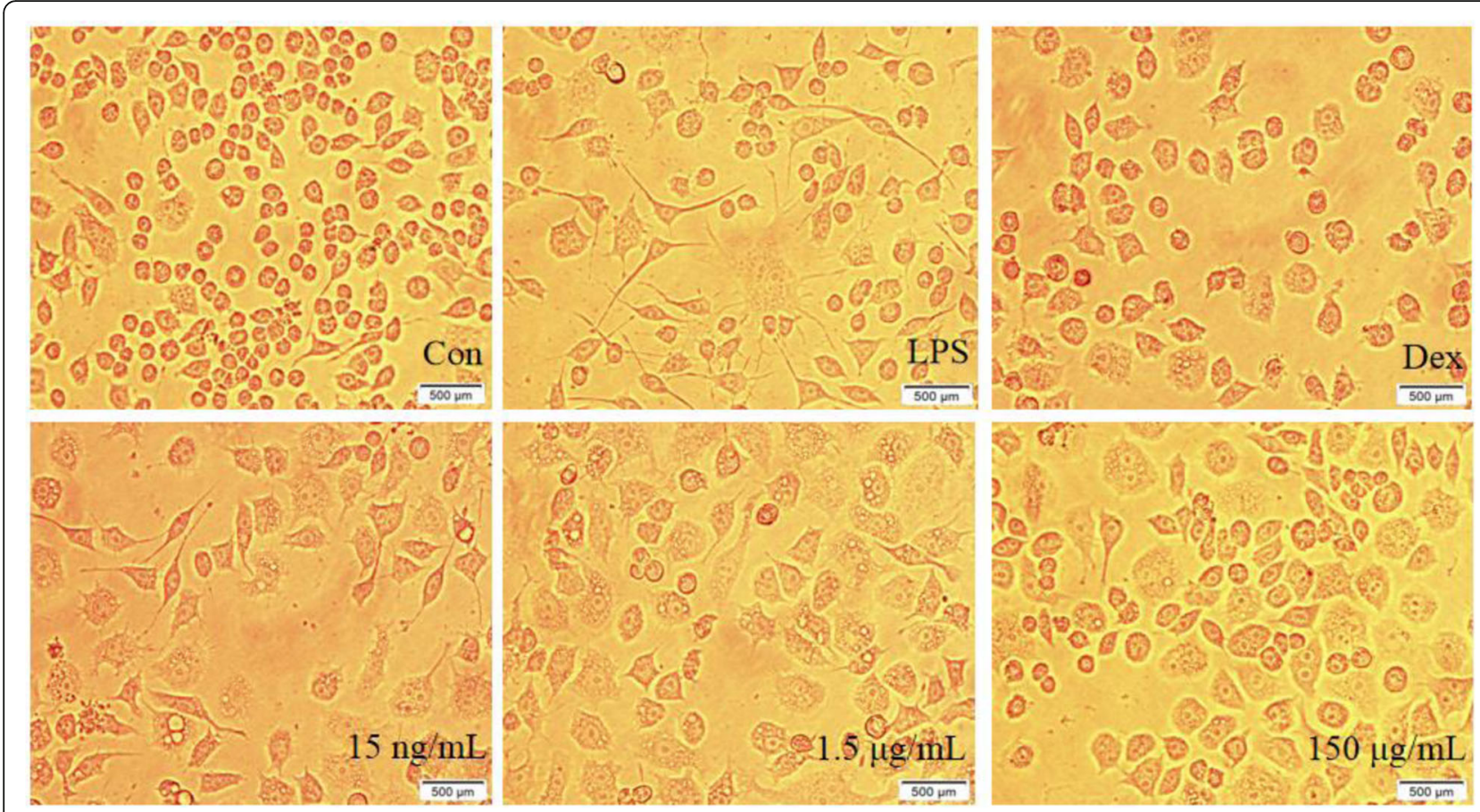

Fig. 2 Cell morphology in each group $(400 \times)$. Cells were incubated with CSSPW $(15 \mathrm{ng} / \mathrm{mL}, 1.5 \mu \mathrm{g} / \mathrm{mL}$ and $150 \mu \mathrm{gg} / \mathrm{mL})$, Dex $(0.13 \mathrm{mg} / \mathrm{mL}) \mathrm{and}$ LPS $(1 \mu \mathrm{g} / \mathrm{mL})$ for $24 \mathrm{~h}$. The morphology of cells in the $1.5 \mu \mathrm{g} / \mathrm{mL}$ and $150 \mu \mathrm{g} / \mathrm{mL}$ groups was more regular than that in the LPS and $15 \mathrm{ng} / \mathrm{mL}$ groups. These results indicated that CSSPW could alleviate LPS-induced formation of pseudopods, irregular shape and cell vacuoles in a dose-dependent manner

\section{Effects on the production of inflammatory factors}

It is accepted that the inflammatory process leads to the production of considerable inflammatory factors. Thus, to investigate the anti-inflammatory activity of CSSPW, we examined the effects of CSSPW on the levels of NO, IL-6, TNF- $\alpha$ and PGE 2 in LPS-induced RAW264.7 cells. As presented in Fig. 3a-d, treatment with LPS significantly promoted the production of NO, TNF- $\alpha$, IL- 6 and $\mathrm{PGE}_{2} \quad(p<0.05$ or $p<0.01)$, whereas CSSPW treatment particularly suppressed this increase in a concentration-dependent manner. In particular, the increased production was inhibited more effectively at $150 \mu \mathrm{g} / \mathrm{mL}$ than at $15 \mathrm{ng} / \mathrm{mL} \quad(p<0.05$ or $p<0.01)$; however, there were no significant differences at $1.5 \mu \mathrm{g} / \mathrm{mL}$.

\section{Effects on the expression levels of COX-2 and iNOS mRNA}

Furthermore, we determined whether the inhibition of $\mathrm{PGE}_{2}$ and NO by CSSPW was due to downregulating the expression of COX-2 and iNOS mRNA. As expected, the expression levels of COX-2 and iNOS mRNA were obviously increased due to LPS stimulation $(p<0.01)$. Different concentrations of CSSPW caused a decrease in the expression of COX-2 and iNOS mRNA to varying degrees. The $1.5 \mu \mathrm{g} / \mathrm{mL}$ and $150 \mu \mathrm{g} / \mathrm{mL}$ groups had more significant effects on the expression levels of COX-2 and iNOS mRNA compared to those of the $15 \mathrm{ng} / \mathrm{mL}$ group $(p<0.01)$, especially those of the $150 \mu \mathrm{g} / \mathrm{mL}$ group (Fig. 4). These results indicated that CSSPW may suppress LPS-induced $\mathrm{PGE}_{2}$ and $\mathrm{NO}$ production by downregulating COX-2 and iNOS mRNA expression in RAW264.7 cells.

\section{Effects on protein expression Nrf2/HO-1 pathway}

RAW264.7 cells exposed to LPS had increased expression of Nrf2 and HO-1 $(p<0.01)$. Interestingly, CSSPW at $1.5 \mu \mathrm{g} / \mathrm{mL}$ and $150 \mu \mathrm{g} / \mathrm{mL}$ further increased the expression levels of Nrf2 and HO-1 proteins $(p<0.01)$, whereas no obvious difference was found in the $15 \mathrm{ng} /$ $\mathrm{mL}$ group $(p>0.05$, Fig. 5$)$.

\section{MAPK pathway}

Treatment with LPS resulted in a significant increase in the phosphorylation of p38, JNK and ERK compared to that of the Con group $(p<0.01)$. The different concentrations of CSSPW greatly reduced the expression levels of these proteins $(p<0.01)$. The effects in the $1.5 \mu \mathrm{g} / \mathrm{mL}$ and $150 \mu \mathrm{g} / \mathrm{mL}$ groups were more significant compared to those of the $15 \mathrm{ng} / \mathrm{mL}$ group $(p<0.01)$, especially those of the $150 \mu \mathrm{g} / \mathrm{mL}$ group (Fig. 6). 


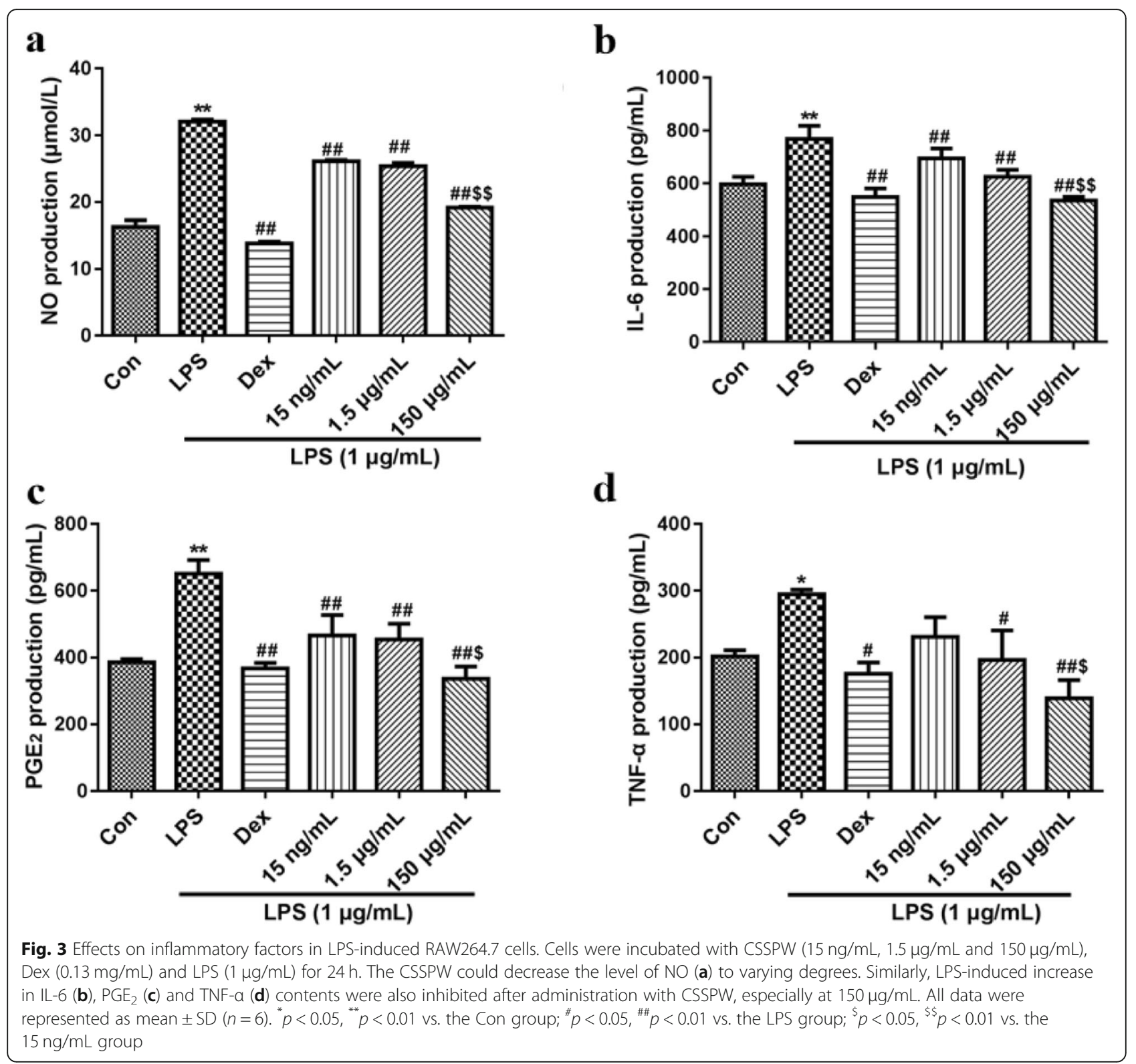

\section{NF-KB pathway}

Figure 7 showed that LPS stimulation resulted in an extreme increase in the phosphorylation of p65 compared to that of the Con group $(p<0.01)$, which was attenuated by CSSPW at different concentrations $(p<0.01)$. Moreover, CSSPW $(150 \mu \mathrm{g} / \mathrm{mL})$ treatment markedly suppressed the phosphorylation of p65 in LPSstimulated RAW264.7 cells compared to that of the 15 $\mathrm{ng} / \mathrm{mL}$ group $(p<0.01)$; however, there was no significant difference in the $1.5 \mu \mathrm{g} / \mathrm{mL}$ group $(p>0.05)$.

Effects on p65 translocation into the nucleus Under normal conditions, p65 was mainly distributed in the cytoplasm. After LPS stimulation, significant green fluorescence was observed in the nuclear region. As shown in Fig. 8, correspondingly, the proportion of p65 in the nucleus following LPS treatment was greatly increased compared to that of the Con group. Interestingly, the addition of CSSPW inhibited the nuclear translocation of p65 with increasing concentrations of the drug, the proportion of p65 into nucleus was decreased.

\section{Effects on ROS production}

ROS content was detected by the fluorescent probe DCFH-DA. As demonstrated in Fig. 9, ROS was increased in LPS-treated macrophages $(p<0.01)$, whereas LPS-induced ROS generation was significantly inhibited by CSSPW treatment $(p<0.01)$. Moreover, the effects in the $150 \mu \mathrm{g} / \mathrm{mL}$ and $1.5 \mu \mathrm{g} / \mathrm{mL}$ groups were better than 


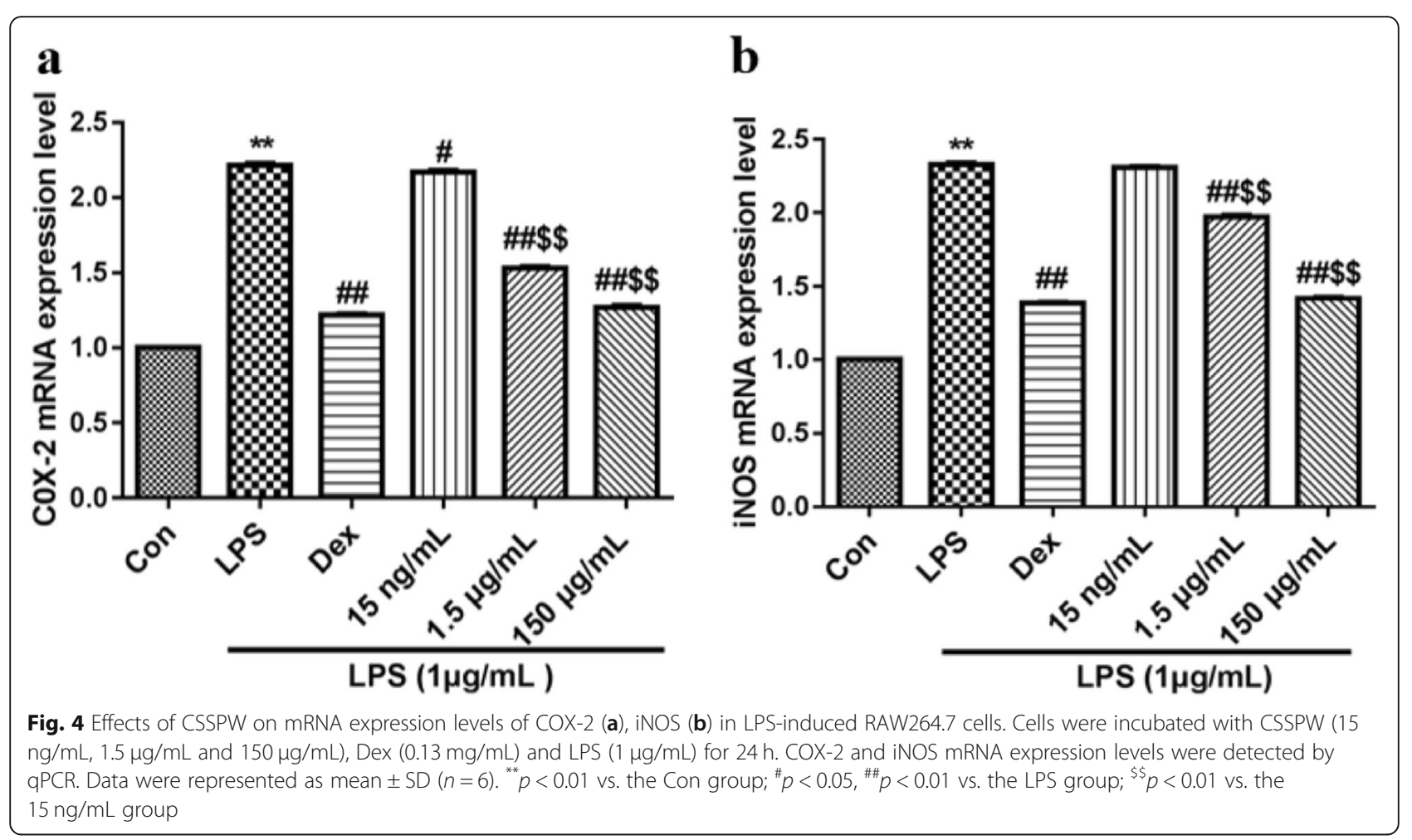

that in the $15 \mathrm{ng} / \mathrm{mL}$ group $(p<0.01)$, especially that in the $150 \mu \mathrm{g} / \mathrm{mL}$ group.

\section{UV fingerprint analysis}

As could be seen from the full-wavelength scanning spectrum of the sample (Fig. 10), the main absorption range was $200-400 \mathrm{~nm}$. CSSPW had absorption peaks at $367 \mathrm{~nm}, 359 \mathrm{~nm}, 323 \mathrm{~nm}, 301 \mathrm{~nm}, 280 \mathrm{~nm}$ and $259 \mathrm{~nm}$. That was, it had absorption at characteristic wavelengths, and there was no interference in the range of visible light.

\section{Discussion}

Inflammation can occur in tissues and organs in different parts of the body, due to conditions such as pneumonia, hepatitis and nephritis. Excessive inflammatory factors produced during inflammation can damage the body directly or indirectly [13]. In this study, RAW264.7 macrophages were used as the research object to elucidate the effect of CSSPW on inflammatory factors and mediators as well as related proteins, thus confirming the anti-inflammatory effect of CSSPW.

Activated RAW264.7 macrophages are involved in many inflammatory responses in the body. Inflammation serves a key role in the host defence system. The bacterial endotoxin LPS stimulates a powerful inflammatory signal that contributes to increased monocyte/macrophage activation and expression of pro-inflammatory cytokines (NO, TNF- $\alpha, \mathrm{IL}-6, \mathrm{PGE}_{2}$, iNOS and COX-2) and pathways (NF-kB, MAPK and Nrf2/HO-1) [14], thereby mediating inflammatory responses [15].

COX-2 and iNOS are key enzymes that promote the generation of $\mathrm{PGE}_{2}$ and $\mathrm{NO}$, respectively, and both can be induced by LPS or other cytokines [16]. The expression levels of COX-2 and iNOS mRNA reflect the degree of cell damage and play synergistic roles in a variety of inflammatory diseases [17]. $\mathrm{PGE}_{2}$ is a classic inflammatory mediator, and its increase leads to the continuation of inflammatory reactions [18]. Inhibiting COX-2 mRNA expression inhibits the production of $\mathrm{PGE}_{2}$, thereby reducing inflammatory damage $[19,20]$. NO changes the permeability of the cell membrane to promote the release of inflammatory factors such as TNF- $\alpha$, IL- 6 and $\mathrm{PGE}_{2}$, which plays a key role in the occurrence and development of inflammation [21, 22]. TNF- $\alpha$, IL- 6 and $\mathrm{PGE}_{2}$ are common inflammatory factors that reflect the severity of inflammation [23]. It has been reported that LPS promotes the synthesis and release of TNF- $\alpha$, IL- 6 and $\mathrm{PGE}_{2}$, thereby aggravating the inflammatory response [24]. Therefore, reducing the levels of inflammatory factors (such as NO, TNF- $\alpha$, IL-6 and $\mathrm{PGE}_{2}$ ), as well as inhibiting the expression of COX-2 and iNOS mRNA, are important measures to prevent inflammatory response [6]. The present study demonstrated that CSSPW could significantly reduce the production of NO, TNF- $\alpha$, IL- 6 and PGE 2 , as well as the expression levels of COX-2 and iNOS mRNA in a dose-dependent manner, suggesting that CSSPW may exert an anti- 


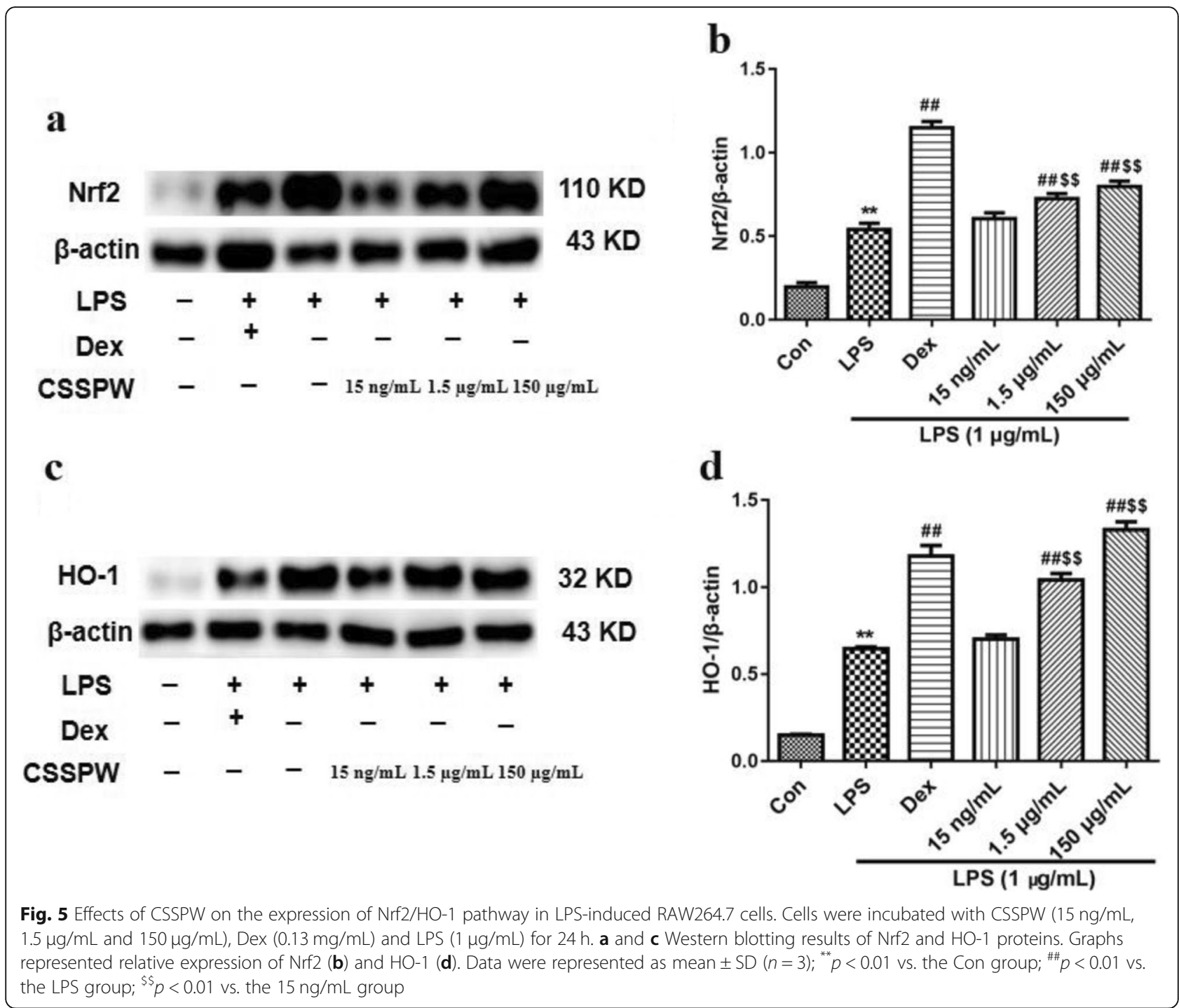

inflammatory effect by inhibiting pro-inflammatory cytokines and mediators. However, we cannot exclude the involvement of other pro-inflammatory cytokines as a possible factor.

Inflammation promotes ROS production, and the overexpression of ROS leads to lipid peroxidation, which may cause serious cell damage. An increase in ROS content is often considered an important indicator of body damage [25]. This study found that CSSPW could inhibit the LPSinduced formation of ROS in a dose-dependent manner, indicating that CSSPW has an anti-inflammatory activity. ROS can also trigger the NF- $\mathrm{BB}$ and MAPK pathways, as well as promote the expression of inflammatory factors such as NO, TNF- $\alpha$, IL- 6 and $\mathrm{PGE}_{2}$, thus exacerbating the inflammatory response [26].

The NF- $\mathrm{BB}$ pathway is generally considered to be a key inflammatory signalling pathway, which is involved in immune and inflammatory responses in vivo, including apoptosis, cell adhesion, cytokine production, etc. [17]. Growing evidence suggests that the NF- $\mathrm{kB}$ pathway mediates inflammatory processes by regulating the expression of the inflammatory response genes (COX-2 and iNOS mRNA) and various pro-inflammatory cytokines [27]. p65, a member of the NF- $\mathrm{BB}$ protein family, is activated to p-p65 under LPS stimulation, resulting in nuclear translocation and the production of various proinflammatory factors (TNF- $\alpha$, IL-6, COX-2, iNOS, etc.), thereby accelerating the inflammatory process $[28,29]$. Hence, the expression of p65 and p-p65 can effectively reflect the degree of NF- $\mathrm{KB}$ activation, and inhibiting the activation of the NF- $k B$ pathway can exert antiinflammatory effects [30, 31]. In this study, CSSPW inhibited LPS-induced p65 protein expression and p65 nuclear translocation in a dose-dependent manner, 

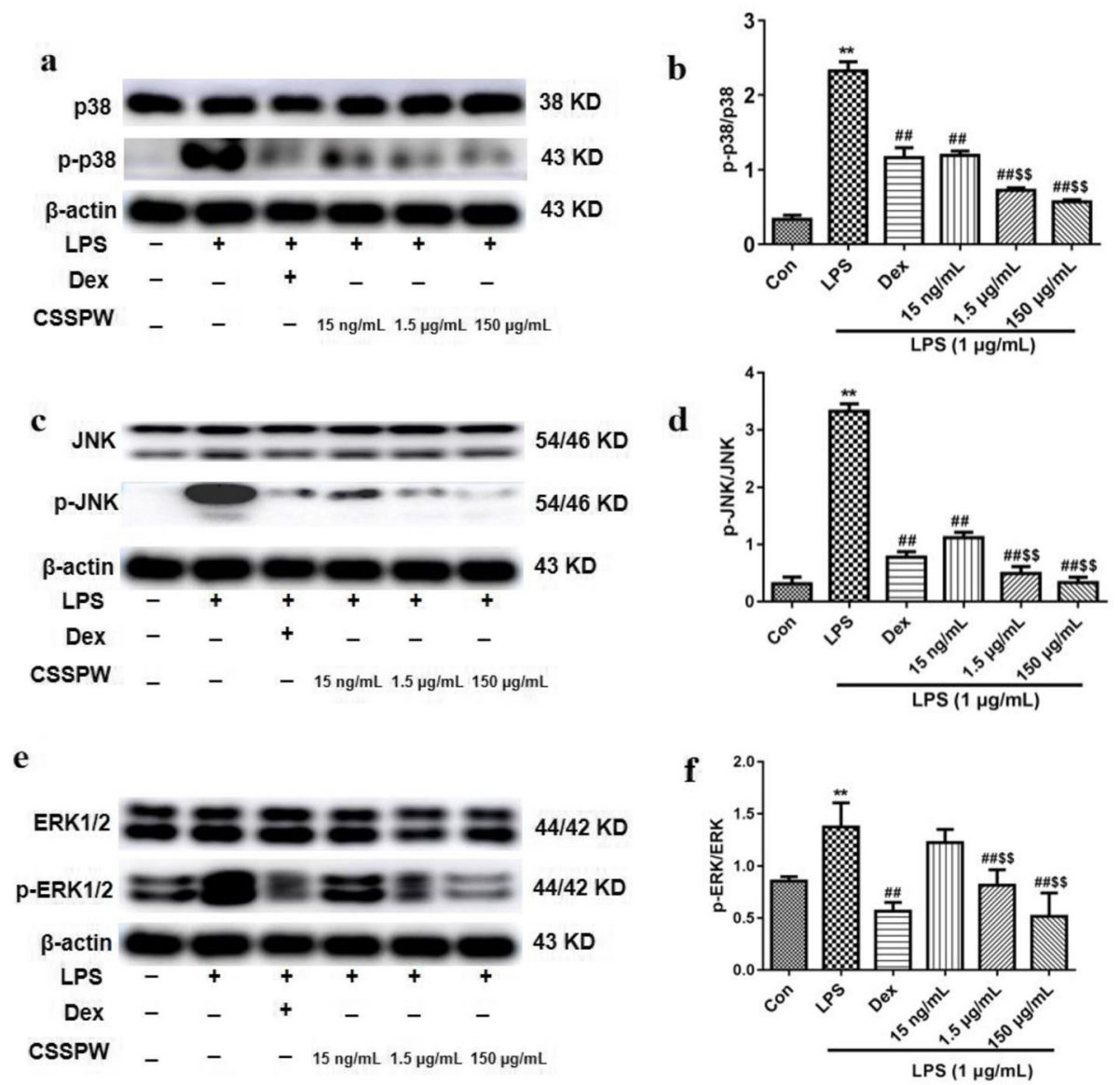

Fig. 6 Effects of CSSPW on the expression of MAPK pathway in LPS-induced RAW264.7 cells. Cells were incubated with CSSPW (15 ng/mL, $1.5 \mu \mathrm{g} /$ $\mathrm{mL}$ and $150 \mu \mathrm{g} / \mathrm{mL})$, Dex $(0.13 \mathrm{mg} / \mathrm{mL})$ and LPS $(1 \mu \mathrm{g} / \mathrm{mL})$ for $24 \mathrm{~h}$. a, c, e Western blotting results of MAPK pathway. Graphs represented relative expression of p-p38/p-38 (b), p-JNKJJNK (d), p-ERK/ERK (f). Data were represented as mean \pm SD $(n=3) ;{ }^{* *} p<0.01$ vs. the Con group; ${ }^{\# \#} p<0.01$ vs. the LPS group; ${ }^{\$} p<0.01$ vs. the $15 \mathrm{ng} / \mathrm{mL}$ group

suggesting that anti-inflammatory effects may be exerted by mediating the NF- $k B$ pathway.

The MAPK pathway can regulate the synthesis or release of pro-inflammatory factors (NO, TNF- $\alpha$ and IL-6) and plays an important role in the inflammatory response [32]. The JNK, p38 and ERK pathways are the three main pathways of the MAPK pathway family and are involved in the inflammatory response; these proteins can be activated and phosphorylated by LPS, thus regulating the downstream inflammatory cytokines [33]. Thus, inhibiting the activation of the MAPK pathway can inhibit the production of NO, TNF- $\alpha$ and IL-6, as well as the expression of COX-2 and iNOS mRNA, further exerting anti-inflammatory effects [34]. In this study, a certain concentration of CSSPW significantly inhibited LPS-induced activation of the p38, JNK and ERK pathways, indicating that CSSPW has antiinflammatory activity. Furthermore, in a certain concentration range, higher concentrations of CSSPW exerted more obvious anti-inflammatory effects. These results suggest that the MAPK pathway may be involved in the inhibitory effect of CSSPW on LPS-stimulated RAW264.7 cells.

The Nrf2/HO-1 signalling pathway also plays a vital role in the process of inflammatory response. LPS can activate Nrf2 through a series of signalling molecules, as well as oxidative stress, and regulate the expression of downstream target proteins (such as HO-1) [32, 35]. The upregulation of Nrf2 can downregulate the production of ROS, thus inhibiting inflammatory responses [36]. HO-1 is a key molecule that regulates the inflammatory response and inhibits the production of pro-inflammatory mediators such as TNF- $\alpha$ and IL-6 [33, 37]. A typical response of cells and tissues to oxidative stress is upregulating the expression levels of Nrf2 and HO-1. For example, ginkgolide exerts its anti-inflammatory activity by upregulating the expression of Nrf2 and HO-1 [38]. In this study, CSSPW at doses of 1.5 and $150 \mu \mathrm{g} / \mathrm{mL}$ could further 

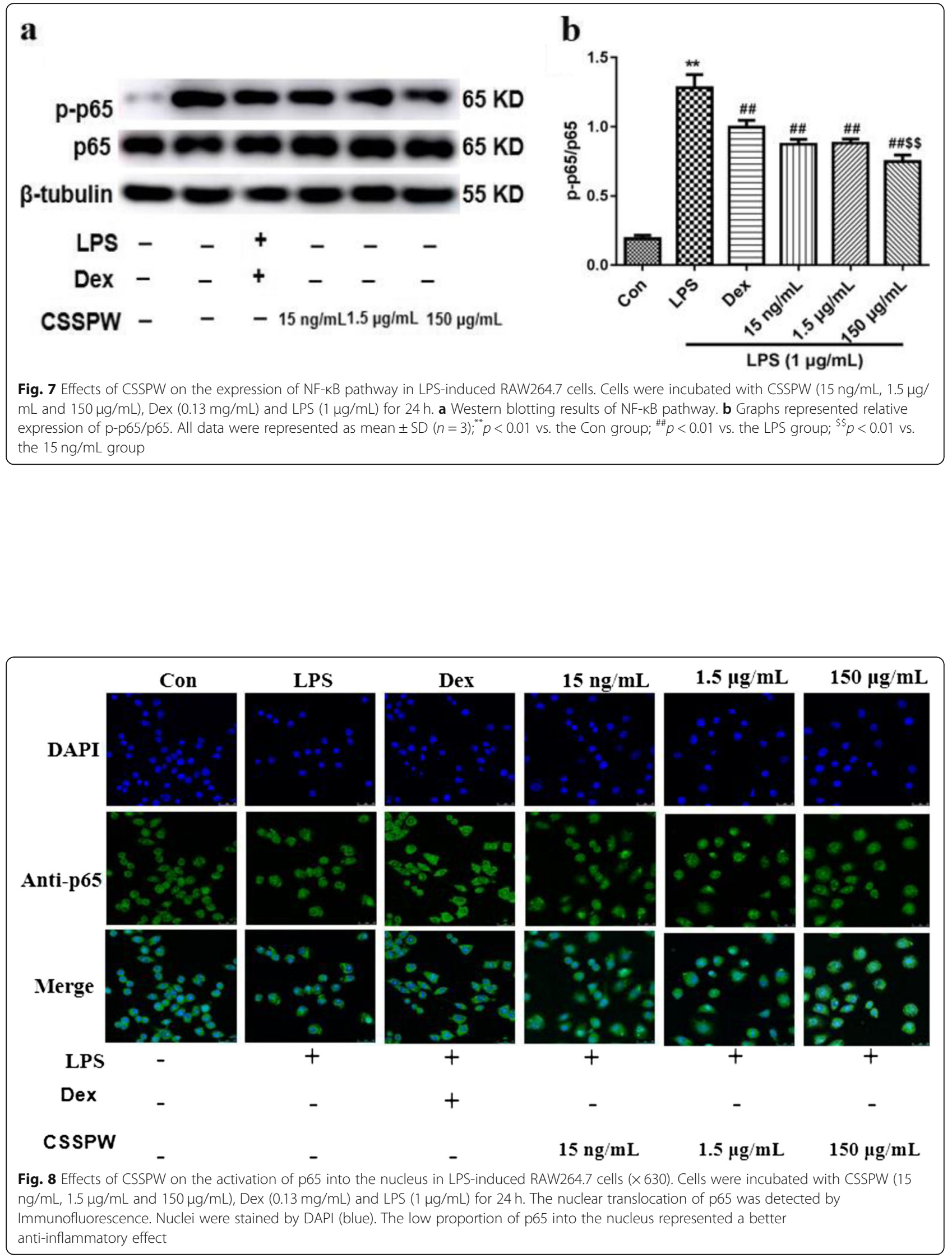


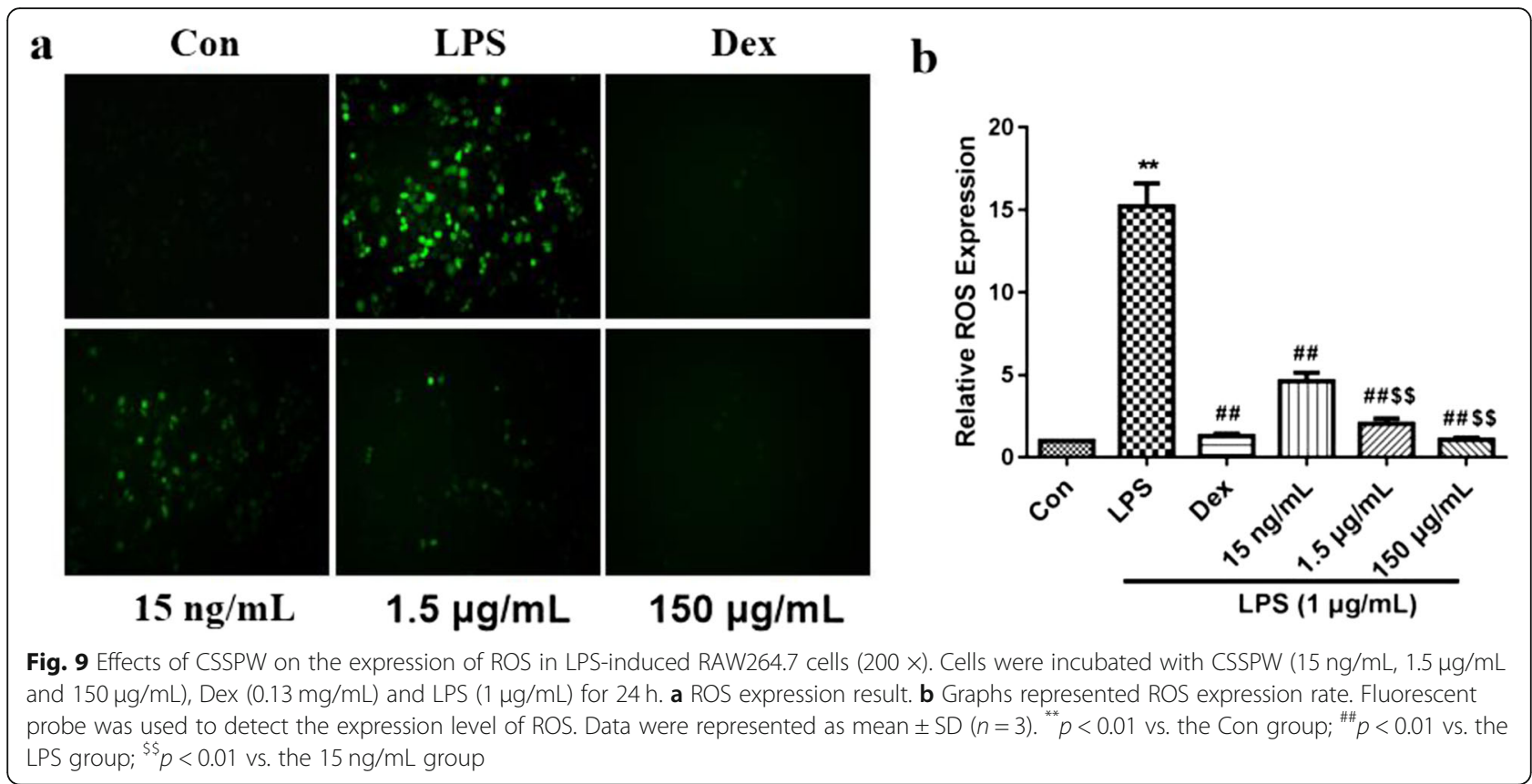

significantly increase the expression of Nrf2 and HO-1 to exert an anti-inflammatory effect; in contrast, the effect of $15 \mathrm{ng} / \mathrm{mL}$ CSSPW was insignificant, suggesting a dosedependent effect.

\section{Conclusions}

In summary, the current study demonstrated that CSSPW may exert anti-inflammatory activity in a dose-dependent manner by suppressing the NF- $\mathrm{KB}$ and MAPK inflammatory pathways and activating the $\mathrm{Nrf} 2 / \mathrm{HO}-1$ pathway to reduce the release of inflammatory factors such as NO, TNF- $\alpha$, IL-6 and PGE 2 in
LPS-stimulated macrophages. To the best of our knowledge, this is the first report of the antiinflammatory activity of $C$. serratus in LPS-induced cells. These results provide evidence for the clinical treatment of inflammatory diseases, indicating that it is possible to develop CSSPW into an effective antiinflammatory medicine. Furthermore, we will test the phosphorylation level of $\mathrm{I} \kappa \mathrm{B}$ protein in the NF- $\kappa \mathrm{B}$ pathway and the phosphorylation of $\mathrm{Nrf2}$ protein in the Nrf2/HO-1 pathway. In the future, we expect to isolate the anti-inflammatory active monomer composition of C. serratus.

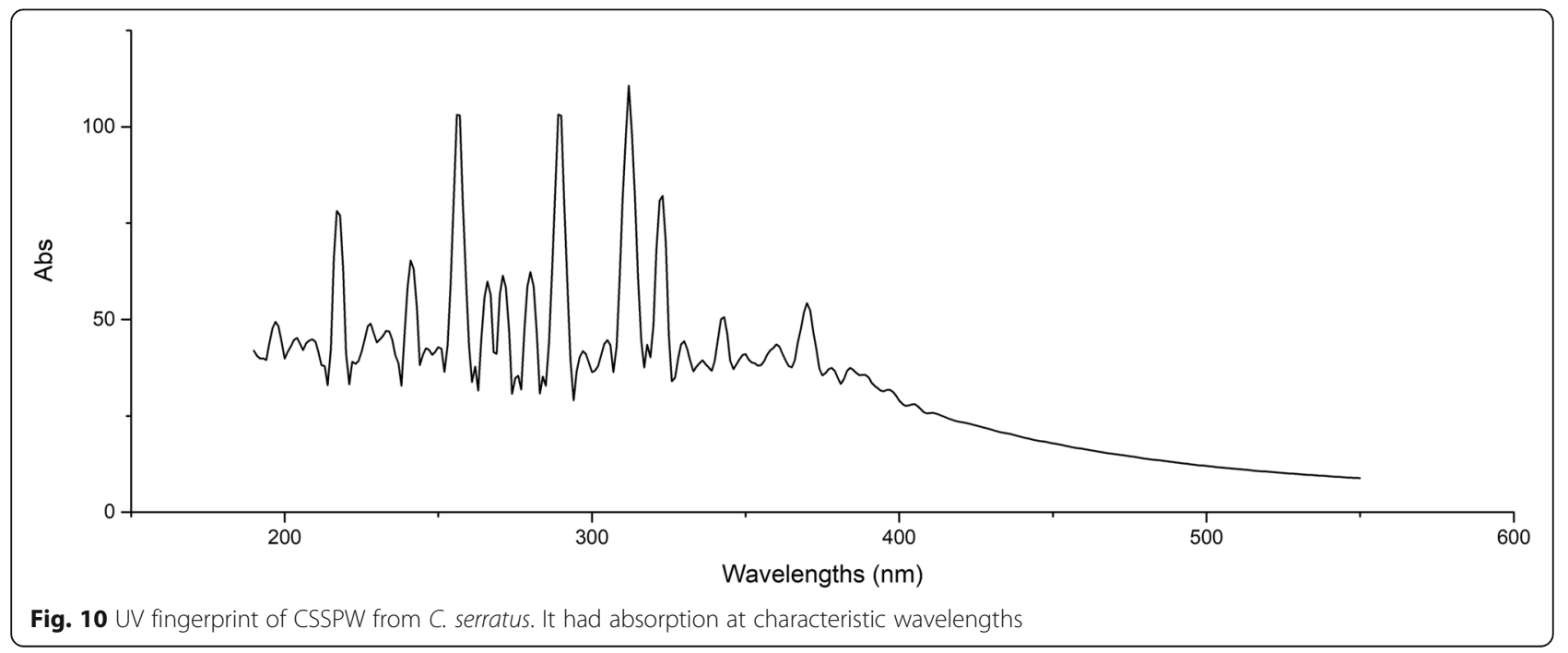




\section{Abbreviations}

C. serratus: Chloranthus serratus; COX-2: Cyclooxygenase-2;

CSSPW: Chloranthus serratus's separated part of water; DMEM: Dulbecco's modified Eagle's medium; IL-6: Interleukin-6; iNOS: Inducible nitric oxide synthase; LPS: Lipopolysaccharide; MAPK: Mitogen-activated protein kinase; NF-kB: Nuclear factor-kappa B; NO: Nitric oxide; Nrf2/HO-1: Nuclear transcription factor E2 related factor 2/heme oxygenase-1; $\mathrm{PGE}_{2}$ : ProstaglandinE $E_{2} ; \mathrm{qPCR}$ : Real-time quantitative PCR; ROS: Reactive oxygen species; TCM: Traditional Chinese medicine; TNF-a: Tumor necrosis factor-a

\section{Acknowledgements}

The authors are grateful to Professor Jianhua Zhu of Wannan Medical College for the identification of plant. The authors are also grateful to Professor Yuekang Xu of Anhui Normal University for the critical reading of the manuscript.

\section{Authors' contributions}

All the authors participated in the whole or partial process of these experiments. $\mathrm{XZ}$ and SS designed the experiments. SS, CY and XS performed the experiments. SS, YD, CY, XS, RW and RX analyzed the data and drafted initial part of the manuscript. All authors read and approved the final manuscript.

\section{Funding}

This work was supported by Key Research and Development Projects (grant no. 1804 h08020271) from Anhui Provincial Department of Science and Technology, China.

\section{Availability of data and materials}

The data presented in this manuscript has not been deposited in any repository yet. However, the materials are available to the researchers upon request.

\section{Ethics approval and consent to participate}

Not applicable for this submission.

\section{Consent for publication}

Not applicable for this submission.

\section{Competing interests}

The authors declare that they have no competing interests.

\section{Author details}

'College of Life Science, Anhui Normal University, Wuhu 241000, Anhui, China. ${ }^{2}$ College of Pharmacy, Wannan Medical College, Wuhu 241002, Anhui, China. Institute of Natural Daily Chemistry, Wannan Medical College, Wuhu 241002, Anhui, China.

\section{Received: 18 August 2019 Accepted: 15 November 2019} Published online: 02 December 2019

\section{References}

1. Huang GJ, Huang SS, Deng JS. Anti-inflammatory activities of inotilone from Phellinus linteus through the inhibition of MMP-9, NF-KB, and MAPK activation in vitro and in vivo. PLoS One. 2012;7(5):e35922.

2. Jang JY, Lee MJ, You BR, Jin JS, Lee SH, Yun YR, Kim HJ. Allium hookeri root extract exerts anti-inflammatory effects by nuclear factor-kB downregulation in lipopolysaccharide-induced RAW264.7 cells. BMC Complement Altern Med. 2017;17(1):126-35.

3. Shin JY, Kang JS, Byun HW, Ahn EK. Regulatory effects and molecular mechanism of Trigonostemonreidioides on lipopolysaccharide-induced inflammatory responses in RAW264.7 cells. Mol Med Rep. 2017;16(4):5137-42.

4. Mirzoeva S, Tong X, Bridgeman BB, Plebanek MP, Volpert OV. Apigenin inhibits UVB-induced skin carcinogenesis: the role of thrombospondin-1 as an anti-inflammatory factor. Neoplasia. 2018;20(9):930-42.

5. Chang SL, Hsiao YW, Tsai YN, Lin SF, Liu SH, Lin YJ, Lo LW, Chung FP, Chao TF, Hu YF, Tuan TC, Liao JN, Hsieh YC, Wu TJ, Higa S, Chen SA. Interleukin-17 enhances cardiac ventricular remodeling via activating MAPK pathway in ischemic heart failure. J Mol Cell Cardiol. 2018;122:69-79.
6. Hsieh IN, Chang ASY, Teng CM, Chen CC, Yang CR. Aciculatin inhibits lipopolysaccharide-mediated inducible nitric oxide synthase and cyclooxygenase-2 expression via suppressing NF-KB and JNK/p38 MAPK activation pathways. J Biomed Sci. 2011;18(1):28-39.

7. Liang N, Sang Y, Liu W, Yu W, Wang X. Anti-inflammatory effects of Gingerol on lipopolysaccharide-stimulated RAW264.7 cells by inhibiting NF-KB signaling pathway. Inflammation. 2018;41(3):835-45.

8. Marilene LDR, Leandra EGO, Camila CMPS, Damiao PDS, Reinaldo NDA, Demetrius AMA. Antinociceptive and anti-inflammatory effects of the monoterpene $a$, $\beta$-epoxy-carvone in mice. J Nat Med. 2013;67(4):743-9.

9. Zhang M, linuma M, Wang JS, Oyama M, Ito T, Kong LY. Terpenoids from Chloranthus serratus and their anti-inflammatory activities. J Nat Prod. 2012;75(4):694-8.

10. Song L. Modern Chinese pharmacy dictionary, vol. 1: People's Health Publishing House; 2001. p. 222-3. https://www.ncbi.nlm.nih.gov/ pubmed/22372956.

11. Sun SP, Li SL. Study on anti-inflammatory effect of alcohol extract of Chloranthus serratus. Chinese Mod Med Distance Educ. 2013;11(7):149-50.

12. Su XD, Guo RH, Li HX, Ma JY, Kim YR, Kim YH, Yang SY. Anti-allergic inflammatory components from Sanguisorba officinalis L. Bioorg Med Chem Lett. 2018;28(12):2210-6.

13. George A, Chinnappan S, Chintamaneni M, Kotak CV, Choudhary Y, Kueper T, Radhakrishnan AK. Anti-inflammatory effects of Polygonum minus (Huds) extract (Lineminu ${ }^{T M}$ ) in in-vitro enzyme assays and carrageenan induced paw edema. BMC Complement Altern Med. 2014;14(1):341-55.

14. Sun HJ, Cai WW, Wang X, Liu YL, Hou B, Zhu XX, Qiu LY. Vaccaria hypaphorine alleviates lipopolysaccharide-induced inflammation via inactivation of NFKB and ERK pathways in raw 264.7 cells. BMC Complement Altern Med. 2017;17(1):120-30.

15. Choi HE, Kwak HJ, Kim SK, Cheon HG. Foenumoside B isolated from Lysimachiafoenum-graecum extract suppresses LPE-induced inflammatory response via NF-KB/AP-1 inactivation in murine macrophages and in endotoxin-induced shock model. Eur J Pharmacol. 2018;832:120-8.

16. Lee KH, Chow YL, Sharmili V, Abas F, Alitheen NBM, Shaari K, Israf DA, Lajis $\mathrm{NH}$, Syahida A. A Curcumin derivative suppresses inflammatory responses in macrophage-like cellular system: role of inhibition in NF-KB and MAPK signaling pathways. Int J Mol Sci. 2012;13(12):2985-3008.

17. Yoon WJ, Moon JY, Song G, Lee YK, Han MS, Lee JS, Ihm BS, Lee WJ, Lee $\mathrm{NH}$, Hyun CG. Artemisia fukudo essential oil attenuates LPS-induced inflammation by suppressing NF-KB and MAPK activation in RAW264.7 macrophages. Food Chem Toxicol. 2010;48(5):1222-9.

18. Li T, Liu B, Mao W, Gao R, Wu J, Deng Y, Shen Y, Liu K, Cao J. Prostaglandin E promotes nitric oxide synthase 2 , platelet-activating factor receptor, and matrix metalloproteinase-2 expression in Escherichia coli-challenged ex vivo endometrial explants via the prostaglandin E receptor 4/protein kinase a signaling pathway. Theriogenology. 2019;134:65-73.

19. Albertini R, Aimbire F, Villaverde AB, Sliva JA Jr, Costa MS. COX-2 mRNA expression decreases in the subplantar muscle of rat paw subjected to carrageenan-induced inflammation after low level laser therapy. Inflamm Res. 2007;56(6):228-9.

20. Song Q, Fan C, Wang P, Li Y, Yang M, Yu SY. Hippocampal CA1 BCaMKII mediates neuroinflammatory responses via $\mathrm{COX}-2 / \mathrm{PGE}_{2}$ signaling pathways in depression. J Neuroinflammation. 2018;15(1):338-54.

21. Lee YJ, Choi DY, Choi IS, Kim KH, Kim YH, Kim HM, Lee K, Cho WG, Jung JK, Han SB, Han JY, Nam SY, Yun YW, Jeong JH, Oh KW, Hong JT. Inhibitory effect of 4-O-methylhonokiol on lipopolysaccharide-induced neuroinflammation, amyloidogenesis and memory impairment via inhibition of nuclear factor-kappaB in vitro and in vivo models. J Neuroinflammation. 2012;9(1):35-54.

22. Lee PJ, Tsai TY, Chen S. Analysis of NO-suppressing activity of strawberry wine supplemented with ball-milled achenes. J Food Sci Technol. 2018; 55(4):1285-94.

23. Badiei A, Muniraj N, Chambers S, Bhatia M. Inhibition of hydrogen sulfide production by gene silencing attenuates inflammatory activity by downregulation of NF-KB and MAPK-inase activity in LPS-activated RAW 264.7 cells. Biomed Res Int. 2014;2014:848570.

24. Lee WH, Wu HM, Lee CG, Sung DI, Song HJ, Matsui T, Kim HB, Kim SG. Specific Oligopeptides in Fermented Soybean extract inhibit NF-KBdependent iNOS and cytokine induction by toll-like receptor ligands. J Med Food. 2014;17(11):1239-46.

25. Ihsan AU, Khan FU, Khongorzul P, Ahmad KA, Naveed M, Yasmeen S, Cao Y, Taleb A, Maiti R, Akhter F, Liao X, Li X, Cheng Y, Khan HU, Alam K, Zhou X. 
Role of oxidative stress in pathology of chronic prostatitis/chronic pelvic pain syndrome and male infertility and antioxidants function in ameliorating oxidative stress. Biomed Pharmacother. 2018;106:714-23.

26. Younis T, Khan MR, Sajid M, Majid M, Zahra Z, Shah NA. Fraxinus xanthoxyloides leaves reduced the level of inflammatory mediators during in vitro and in vivo studies. BMC Complement Altern Med. 2016;16(1):230-46.

27. Yodkeeree S, Ooppachai C, Pompimon W, Limtrakul P. OMethylbulbocapnine and Dicentrinesuppress LPS-induced inflammatory response by blocking NF-KB and AP-1 activation through inhibiting MAPKs and Aktsignaling in RAW264.7 macrophages. Biol Pharm Bull. 2018;41(8): 1219-27.

28. Li Y, Liu H, Xu QS, Du YG, Xu J. Chitosan oligosaccharides block LPS-induced $\mathrm{O}-\mathrm{GlcNAcylation}$ of NF-KB and endothelial inflammatory response. Carbohydr Polym. 2014;99:568-78.

29. Kang NJ, Han SC, Kang GJ, Koo DH, Koh YS, Hyun JW, Lee NH, Ko MH, Kang HK, Yoo ES. Diphlorethohydroxycarmalol inhibits interleukin-6 production by regulating NF-KB, STAT5 and SOCS1 in lipopolysaccharide-stimulated RAW264.7 cells. Mar Drugs. 2015;13(4):2141-57.

30. Lee SY, Lee KS, Yi SH, Kook SH, Lee JC. Acteoside suppresses RANKLmediated osteoclastogenesis by inhibiting c-Fosinduction and NF-KB pathway and attenuating ROS production. PLoS One. 2013;8(12):e80873.

31. Yang L, Chen J, Han X, Zhang E, Huang X, Guo X, Chen Q, Wu W, Zheng G, He D, Zhao Y, Yang Y, He J, Cai Z. Pirh2 mediates the sensitivity of myeloma cells to bortezomib via canonical NF-kB signaling pathway. Protein Cell. 2018;9(9):770-84.

32. Ye J, Piao HM, Jiang JZ, Jin GY, Zheng MY, Yang JS, Jin X, Sun T, Choi YH, Li LC, Yan GH. Polydatin inhibits mast cell-mediated allergic inflammation by targeting PI3K/Akt, MAPK, NF-KB and Nrf2/HO-1 pathways. Sci Rep. 2017; 7(1):11895.

33. Kim KS, Cui X, Lee DS, Ko W, Sohn JH, Yim JH, An RB, Kim YC, Oh H. Inhibitory effects of benzaldehyde derivatives from the marine Fungus Eurotium sp. SF-5989 on inflammatory mediators via the induction of Heme Oxygenase-1 in lipopolysaccharide-stimulated RAW264.7 macrophages. Int J Mol Sci. 2014;15(12):23749-65.

34. Song S, Dang M, Kumar M. Anti-inflammatory and renal protective effect of gingerol in high-fat diet/streptozotocin-induced diabetic rats via inflammatory mechanism. Inflammopharmacology. 2019:1-12. https://scihub.tw/10.3390/ijms151223749.

35. Zhang W, Song JK, Yan R, Li L, Xiao ZY, Zhou WX, Wang ZZ, Xiao W, Du GH. Diterpene ginkgolides protect against cerebral ischemia/reperfusion damage in rats by activating Nrf2 and CREB through PI3K/Akt signaling. Acta Pharmacol Sin. 2018;39(8):1259-72.

36. Lv Q, Wang K, Qiao SM, Dai Y, Wei ZF. Norisoboldine, a natural aryl hydrocarbon receptor agonist, alleviates TNBS-induced colitis in mice, by inhibiting the activation of NLRP3 inflammasome. Chin J Nat Med. 2018; 16(3):161-74.

37. Jin CH, So YK, Han SN, Kim JB. Isoegomaketoneupregulates Heme Oxygenase-1 in RAW264.7 cells via ROS/p38 MAPK/Nrf2 pathways. Biomol Ther. 2016;24(5):510-6.

38. Huang S, Meng N, Chang BQ, Quan XH, Yuan RY, Li B. Anti-inflammatory activity of Epimedium brevicornu Maxim ethanol extract. J Med Food. 2018; 21(7):726-33.

\section{Publisher's Note}

Springer Nature remains neutral with regard to jurisdictional claims in published maps and institutional affiliations.

Ready to submit your research? Choose BMC and benefit from:

- fast, convenient online submission

- thorough peer review by experienced researchers in your field

- rapid publication on acceptance

- support for research data, including large and complex data types

- gold Open Access which fosters wider collaboration and increased citations

- maximum visibility for your research: over $100 \mathrm{M}$ website views per year

At BMC, research is always in progress.

Learn more biomedcentral.com/submissions 